\title{
Jak reformować polski system podatkowy - mity i fakty
}

https://doi.org/10.33141/po.2005.09.06

\section{Tomasz Wołowiec}

Przegląd Organizacji, Nr 9 (788), 2005, ss. 28-31 www.przegladorganizacji.pl Towarzystwo Naukowe Organizacji i Kierownictwa (TNOiK)
Planując reformę systemu podatkowego, możemy wskazać na pewne teoretyczne wymagania dobrego systemu podatkowego. Współcześnie system podatkowy powinien uwzględniać następujące kwestie (zasady) ${ }^{1)}$ :

- zasadę korzyści - oznaczającą, że ludzie powinni płacić podatki proporcjonalnie do korzyści, które osiągają z konsumpcji dóbr publicznych;

- zasadę możliwości zapłaty- oznaczającą, że wysokość podatku powinna być uzależniona od możliwości jego zapłaty przez podatnika;

- sprawiedliwość poziomą - oznaczającą równe traktowanie osób, które znajdują się w takiej samej sytuacji („równi powinni być traktowani równo”);

- sprawiedliwość pionową - zgodnie z którą osoby w lepszej sytuacji płacą większe podatki niż te w gorszej sytuacji („nierówni powinni być traktowani nierówno");

- niskie koszty poboru - koszty te powinny być sprowadzone do minimum;

- nieuchronność opodatkowania - po to, by podatnik nie starał się uniknąć czy ominać podatku;

- neutralność - system podatkowy nie powinien zniekształcać alokacji dokonującej się na rynku, w tym szczególnie nie powinien negatywnie wpływać na decyzje dotyczące podaży pracy i kapitału;

- dogodność dla podatników - system powinien być prosty, przejrzysty i zrozumiały dla podatników.

Decydując się na reformowanie polskiego systemu podatkowego, należy zwrócić uwagę na następujące fakty $^{2)}$.

- Używając współczynnika korelacji Pearsona można zbadać siłę i kierunek zależności między poziomem fiskalizmu a średniorocznym tempem wzrostu $\mathrm{PKB}^{3)}$. Dla 14 krajów UE, badanych w latach 1991-2000, uzyskana wartość współczynnika korelacji liniowej wynosi rxy=-0,56. Wynik ten pozwala stwierdzić, że średnie tempo wzrostu gospodarczego badanych 14 państw w $31 \%$ wyjaśniane jest przez średni poziom fiskalizmu. Zatem wzrost poziomu fiskalizmu o $1 \%$ powodował w tych krajach spadek tempa wzrostu gospodarczego per capita o $0,14 \%$.

- Analizując wpływ udziału podatków dochodowych w dochodach fiskalnych na tempo wzrostu PKB uzyskujemy współczynnik korelacji liniowej Pearsona na poziomie rxy=0,12. Uzyskana wartość współczynnika oznacza, że nie występuje istotna statystycznie zależność między udziałem podatków dochodowych w dochodach fiskalnych a średniorocznym tempem wzrostu PKB. Badając siłę i kierunek korelacji między PIT i CIT osobno a średniorocznym tempem wzrostu gospodarczego uzyskujemy również nieistotne statystycznie zależności. Uzyskane współczynniki korelacji wynoszą odpowiednio $\mathrm{rxy}=0,05$ i rxy $=0,37$. Zatem udział podatków dochodowych w strukturze budżetowych dochodów fiskalnych nie ma istotnego wpływu na dynamikę wzrostu gospodarczego (w krótkim i długim okresie).

- Badając związek pomiędzy udziałem podatków pośrednich a wzrostem PKB uzyskujemy współczynnik korelacji $r x y=0,72$. Swiadczy to o istnieniu istotnej statystycznie (silnej) zależności pomiędzy udziałem wpływów z opodatkowania pośredniego w łącznych wpływach fiskalnych a tempem wzrostu PKB. Wzrost udziału podatków pośrednich w dochodach fiskalnych o $1 \%$ powoduje wzrost PKB per capita o $0,18 \%$.

Uzyskane wyniki pozwalają postawić tezę, że kraje mające wyższy udział podatków pośrednich w strukturze dochodów fiskalnych generują bardziej dynamiczny wzrost gospodarczy. Korelacja między udziałem podatków pośrednich w dochodach fiskalnych a średniorocznym tempem wzrostu PKB jest silniejsza, niż związek poziomu fiskalizmu z dynamiką wzrostu gospodarczego. Należy podkreślić, że zmiany udziału podatków pośrednich w strukturze dochodów fiskalnych nie wywołują natychmiastowych zmian w tempie wzrostu PKB. Zatem, podobnie jak w przypadku fiskalizmu, struktura dochodów fiskalnych oddziałuje na wzrost gospodarczy w długim okresie.

- Eacząc w jedna grupę podatek dochodowy od osób fizycznych i składki na ubezpieczenia społeczne uzyskujemy kategorię dochodów obciążających pracę. Świadczenia te mają charakter komplementarny i stanowią o tzw. klinie podatkowym (tax wedge), czyli kosztach pracy (różnica pomiędzy kosztem pracy kosztem płacowym dla przedsiębiorcy a płacą netto dochodem płacowym), niezwykle istotnych dla skłonności przedsiębiorców do tworzenia nowych miejsc pracy. Uzyskany współczynnik korelacji rxy=-0,55, oznacza istnienie istotnej statystycznie ujemnej zależności między udziałem obciążeń dochodów z pracy w dochodach fiskalnych a tempem wzrostu PKB. Obliczony na tej podstawie współczynnik determinacji informuje, że średnie tempo wzrostu gospodarczego w badanych latach wyjaśniane jest w $29 \%$ przez udział obciążeń dochodów z pracy w łącznych wpływach fiskalnych.

Uzyskane wyniki pozwalają stwierdzić, że wzrost przeciętnego udziału obciążeń płac w łącznych dochodach fiskalnych o $1 \%$ powoduje spadek PKB per capita 
o 0,11\%. Można zatem stwierdzić, że wysoki poziom obciążeń dochodów z pracy wpływa negatywnie na wzrost gospodarczy. Wysokie koszty pracy pogarszają konkurencyjność gospodarki krajowej, zwiększają skłonność do przechodzenia do szarej strefy i bezrobocie, a konsekwencji hamują wzrost gospodarczy.

- Przyjmując założenie, że podatek dochodowy zmniejsza bodźce do pracy przez redukcję poziomu wynagrodzeń, to zmniejszenie wysokości podatku dochodowego spowoduje zwiększenie bodźców do pracy i powiększania dochodów.

Jest to pogląd jedynie częściowo słuszny, podatnicy w wyniku zmniejszenia dochodu netto przez wzrost podatku mogą bowiem być mobilizowani do pracy, aby zaspokoić swoje potrzeby konsumpcyjne. Ponadto zwiększenie dochodu netto, poprzez obniżenie podatku może spowodować, że podatnicy szybciej zaspokoja swoje potrzeby konsumpcyjne i zmaleje skłonność do dodatkowej aktywności w powiększaniu dochodu. Zatem skutkiem obniżenia poziomu opodatkowania może być spowolnienie tempa wzrostu PKB, bowiem redukcja poziomu stóp podatkowych poprawia sytuację materialna podatników, a w konsekwencji zmniejsza podaż pracy. Należy również pamiętać, że w sytuacji „nasycenia” systemu podatkowego licznymi ulgami o charakterze inwestycyjnym, obniżka podatków osłabia ich motywacyjne działanie.

W krótkim okresie trudno jest wykazać zależność między redukcją stóp podatkowych a tempem wzrostu PKB. Ujemna korelacja oznacza, że wzrost PKB jest tym mniejszy, im wyższy poziom krańcowych stóp podatkowych. Otrzymane współczynniki korelacji sa statystycznie nieistotne, zatem nie ma podstaw do odrzucenia hipotezy o istnieniu związku między poziomem krańcowych stóp podatkowych w krótkim okresie. Wyniki te nie pozwalaja potwierdzić teoretycznych postulatów szkoły ekonomii podaży, zgod- nie z którymi redukcja krańcowych stóp podatkowych prowadzi do obniżki kosztów, pobudzenia produkcji, a w konsekwencji przesunięcia krzywej podaży globalnej tak, aby punkt równowagi popytu z podażą wyznaczał wyższy poziom PKB i niższy poziom cen. Działanie to ma prowadzić do wzrostu gospodarczego i obniżenia inflacji. Efektem tych działań może być wzrost deficytu handlowego, spowodowanego rosnącym popytem na dobra konsumpcyjne i inwestycyjne oraz zwiększenie nadwyżki kapitału, z powodu zwiększenia napływu kapitałów z zagranicy i zmniejszenia wypływu kapitału krajowego za granicę.

Podsumowując należy pamiętać, że każde zwiększanie obciążeń podatkowych i parapodatkowych może przekładać się na spadek tempa wzrostu gospodarczego. Z uzyskanych wyników badań nasuwa się wniosek, że lepszym rozwiązaniem dla wzrostu gospodarczego jest zwiększanie obciążeń fiskalnych podatkami pośrednimi, niż zwiększanie obciążeń pracy. Z badań wynika, że najbardziej negatywny wpływ na wzrost gospodarczy, a szczególnie na poziom bezrobocia, mają obciążenia fiskalne stanowiące o tzw. kosztach pracy. Wbrew obiegowym opiniom badania nie wykazały żadnej korelacji między wpływem obciążeń gospodarki podatkami dochodowymi a wzrostem gospodarczym.

Uzyskane wyniki badań nie pozwalają bez szczegółowych analiz mikroekonomicznych (poziom zamożności gospodarstw domowych, struktura wydatków społeczeństwa, elastyczność cenowa popytu itd.) postawić tezy, że bardziej korzystne z punktu widzenia dobrobytu społeczno-ekonomicznego jest zwiększanie w strukturze podatkowych dochodów budżetowych wpływów z opodatkowania pośredniego. Obniżka obciążeń z tytułu podatków dochodowych wymaga, dla zachowania neutralności wpływów, wzrostu obciążeń podatkami pośrednimi.

Tab. Wpływ redukcji podatku dochodowego (państwowego) na wzrost gospodarczy w latach 1992-1996 w wybranych krajach OECD

\begin{tabular}{|l|c|c|c|c|c|c|c|}
\hline & \multirow{2}{*}{$\begin{array}{c}\text { Redukcja } \\
\text { Kraj }\end{array}$} & \multicolumn{5}{c|}{ Tempo wzrostu PKB (w \%) } \\
\cline { 3 - 7 } & $\mathbf{1 9 9 2}$ & $\mathbf{1 9 9 3}$ & $\mathbf{1 9 9 4}$ & $\mathbf{1 9 9 5}$ & $\mathbf{1 9 9 6}$ & Średnio \\
\hline Australia & 17 & 3 & 4 & 5 & 3 & 4 & 3,8 \\
Austria & 12 & 2 & 0 & 3 & 2 & 1 & 1,6 \\
Finlandia & 12 & -4 & -1 & 4 & 4 & 2 & 1,0 \\
Francja & 3 & 1 & -1 & 3 & 2 & 1 & 1,2 \\
Holandia & 12 & 2 & 1 & 3 & 2 & 3 & 2,2 \\
Japonia & 25 & 1 & 0 & 0 & 1 & 4 & 1,2 \\
Kanada & 14 & 1 & 2 & 4 & 2 & 2 & 2,2 \\
Niemcy & 3 & 2 & -1 & 3 & 2 & 1 & 1,4 \\
Norwegia & 35 & 3 & 3 & 5 & 3 & 5 & 3,8 \\
USA & 39 & 2 & 3 & 4 & 2 & 2 & 2,6 \\
Szwecja & 37 & -1 & -2 & 3 & 4 & 2 & 1,2 \\
Włochy & 22 & 1 & -1 & 2 & 3 & 1 & 1,2 \\
Wielka Brytania & 43 & -1 & 2 & 4 & 2 & 2 & 1,8 \\
\hline Korelacja między podatkami a PKB (Rxy) & $-0,09$ & 0,36 & 0,14 & 0,14 & 0,36 & 0,27 \\
\hline Korelacja dla krajów o skali redukcji & & & & & & $-0,07$ & $-0,10$ \\
\hline
\end{tabular}

Źródło: J. ŻYŻYŃSKI, Podatki pośrednie i bezpośrednie - problemy i fakty, „Ekonomista”, nr 5/2002, s. 747. 
Należy jednak pamiętać, że może wywołać to pewne negatywne konsekwencje.

- Wzrost efektywnych stawek podatku od towarów i usług może prowadzić do niekorzystnej alokacji produkcji w kierunku dóbr o niższej cenowej elastyczności popytu. Podatki pośrednie wykorzystują preferencje użyteczności konsumentów, w celu zaspokojenia potrzeb finansowych budżetu, ale struktura gospodarki przesuwa się w kierunku dóbr o niskiej elastyczności popytu (dóbr podstawowych). Stanowić to może czynnik osłabiajacy wzrost gospodarczy poprzez zmniejszenie rynku na dobra wyższego rzędu, stymulujące konkurencyjność gospodarki.

- Wywołane przez wzrost stawek podatków pośrednich podwyższenie cen może prowadzić do wzrostu procesów inflacyjnych. Jeżeli nastąpi wzrost cen dóbr konsumpcyjnych o niskiej elastyczności popytu, to niska elastyczność nie spowoduje spadku popytu (lub niewielki spadek). Producenci zwiększą ceny, co spowoduje mnożnikową reakcję innych cen. Gospodarstwa domowe obciążone wyższymi cenami dóbr podstawowych ograniczają popyt na dobra wyższego rzędu, przez co obniża się ich cena i produkcja. Producenci zmniejszają produkcję i o ogólnym poziomie cen decydują dobra o niskiej cenowej elastyczności popytu. - Wysokie (rosnące) stawki podatków pośrednich poprzez podniesienie poziomu cen i efekt inflacyjny powodują obniżenie realnych dochodów społeczeństwa, obniżenie popytu, spadek produkcji, a w konsekwencji osłabienie tempa wzrostu gospodarczego.

- Wzrost cen, będący efektem rosnących stawek podatków pośrednich generuje w dłuższym okresie presję na wzrost wynagrodzeń, aby nie osłabiać globalnego popytu w gospodarce. Powoduje to wzrost kosztów wynagrodzeń i kosztów innych czynników produkcji (dostawcy tych czynników poprzez wzrost żądanej ceny kompensują sobie koszty, poprzez przerzucenie obciążenia podatkowego).

- Podatki pośrednie obciążając wydatki konsumpcyjne najsilniej osłabiaja dochodowo gospodarstwa ubogie (w warunkach krajów NMS - New Member States gospodarstwa te generują $80 \%$ globalnego popytu), co oznacza naruszenie zasady równości i sprawiedliwości opodatkowania.

- W sytuacji, gdy wzrost opodatkowania pośredniego w większym stopniu dotyczy dóbr krajowych niż importowanych, powoduje to pogorszenie sytuacji krajowych producentów.

- Wzrost opodatkowania pośredniego dóbr podstawowych powoduje wzrost rozwarstwienia społecznego, poprzez narastanie nierówności ekonomicznych w podziale dochodu narodowego, szczególnie w warunkach wysokiego udziału wydatków gospodarstw domowych na dobra podstawowe (zjawisko to jest typowe dla krajów NMS, zgodnie z prawami Engla).

Istotna jest kompleksowa analiza otoczenia - całokształtu warunków ekonomicznych i społecznych funkcjonowania podatników (podmiotów gospodar(zych) $)^{4)}$.

Ocena wpływu podatków na zachowania podatników, a w konsekwencji na wzrost gospodarczy wymaga uwzględnienia całego otoczenia zewnętrznego, w którym podatki są jednym $\mathrm{z}$ istotnych elementów, ale nie jest to element samodzielnie funkcjonujący i determinujaccy wzrost gospodarczy.

Cechą otoczenia jest zarówno to, że może ono działać hamująco lub stymulująco na wzrost gospodarczy, jak i to, że kształtuje się ono niezależnie od woli podatników.

W otoczeniu można wyróżnić następujące części:

- stan rynku (ceny i kursy walutowe, stan i natężenie konkurencji, zatory płatnicze, stan koniunktury itp.),

- infrastrukturę społeczną i materialną (system bankowy i ubezpieczeniowy, edukację, korupcję, stan administracji, wymiar sprawiedliwości itp.),

- politykę fiskalną i monetarną państwa (cła, pomoc publiczną, wysokość deficytu budżetowego, stopę procentową, podatki i ulgi podatkowe itp.),

- oddziaływanie regulacyjne i administracyjne państwa (regulacje prawne w poszczególnych branżach, regulacje rynku pracy, normy sanitarne UE, kształtowanie jakości produkcji itp.).

Uwzględniając charakter oddziaływania poszczególnych części otoczenia na decyzje i zachowania podatników (przedsiębiorstw i gospodarstw domowych), można podzielić je na trzy grupy ${ }^{5)}$

- elementy otoczenia oddziałujące zarówno stymulująco, jak i hamująco;

- elementy, które zawsze mogą stać się hamulcem lub barierą rozwoju podmiotów gospodarczych, a stymulują rozwój tylko w określonych okolicznościach i warunkach;

- elementy oddziałujące wyłącznie hamująco, powodujące stały wzrost kosztów własnych i obciążeń finansowych podmiotów gospodarczych.

W grupie pierwszej największe znaczenie ma dobry stan koniunktury. Dobra koniunktura cechuje się nadwyżką globalnego popytu nad globalną podażą i oznacza wzrost produkcji, sprzedaży i konsumpcji.

Różnokierunkowy wpływ na funkcjonowanie podatników ma wysokość podatków. Redukcja obciążeń podatkowych podmiotów gospodarczych pozostawia w ich dyspozycji większą część zysku, która może być przeznaczona na inwestycje (rozwój). Stopień, w jakim nie opodatkowane zasoby zwiększą inwestycje zależy od stanu koniunktury. Przedsiębiorstwo nie będzie realizować dodatkowych inwestycji w warunkach nie wykorzystanych mocy produkcyjnych i malejącego popytu na swoje produkty.

W inny sposób oddziałuje wzrost opodatkowania (wysoki poziom obciążeń podatkowych). Może zniechęcać do podejmowania nie tylko nowych inwestycji, ale i rozpoczynania działalności gospodarczej. W krajach transformacji, gdzie zewnętrzne formy finansowania inwestycji są mniej dostępne (wysokie stopy procentowe kredytów), niska kwota zysku pozostająca po opodatkowaniu może być niewystarczającym źródłem finansowania inwestycji. Zatem szczególnie w tych krajach wysoki poziom opodatkowania zysków, a w konsekwencji zmniejszenie dostępnych środków na inwestycje, może być czynnikiem hamującym rozwój przedsiębiorstw.

Do grupy czynników działających silniej na ograniczanie niż pobudzanie rozwoju przedsiębiorstwa należą niewątpliwie regulacje prawne zawarte w ob- 
szarze funkcjonowania rynku pracy. Regulacje te dotyczą głównie:

- wysokości płacy minimalnej i relacji do poziomu zasiłków dla bezrobotnych,

- funkcjonowania elastycznych form zatrudnienia,

- kosztów zwalniania pracowników,

- uciążliwości prawno-administracyjnej (procedur) w zakresie zakładania firm i ich funkcjonowania oraz tworzenia nowych miejsc pracy,

- stopnia skomplikowania i różnorodności regulacji ogólnych i branżowych oraz ich interpretacji przez różnorodne urzędy i instytucje.

Czynniki tworzące otoczenie można identyfikować według celów, jakie mają do spełnienia. Możemy wyróżnić instrumenty kształtujące zachowania podmiotów gospodarczych (stopa procentowa, kursy walutowe, cła itp.), jak i instrumenty tworzone w celu realizacji różnych zadań społecznych i ekonomicznych, których oddziaływanie na zachowania podmiotów gospodarczych jest tylko dodatkowym skutkiem. Do tej grupy instrumentów zaliczamy m.in. podatki.

Ocena poszczególnych podatków, z uwzględnieniem otoczenia, opiera się na teoretycznej analizie roli podatków: dochodowego od osób fizycznych, dochodowego od osób prawnych oraz podatków pośrednich (łacznie).

Niewątpliwie obniżka każdego z omawianych podatków powoduje zwiększenia środków do dyspozycji zarówno przedsiębiorstw, jak i gospodarstw domowych. Czy uzyskane w ten sposób dodatkowe dochody będą stymulowały wzrost gospodarczy, będzie zależało od wielu czynników mikro- i makroekonomicznych. Efektywność i skuteczność oddziaływania poszczególnych podatków (polityki podatkowej) na zjawiska gospodarcze musi uwzględniać całość otoczenia zewnętrznego, czyli całokształt warunków determinujących zasady, warunki i specyfikę funkcjonowania zarówno przedsiębiorstw, jak i gospodarstw domowych.

dr Tomasz Wotowiec

Katedra Ekonomii Wyższej Szkoły Biznesu - National-Louis University w Nowym Sączu

\section{PRZYPISY}

1) J. NENEMAN, R. PIWOWARSKI, Jaki system podatko$w y$, CASE, Warszawa 2004, s. 14.

2) Szeroka analiza oceny wpływu opodatkowania na wzrost gospodarczy wraz z wykazem szczegółowej literatury została przedstawiona w pracy: M. BUDZISZ, Stabilny wzrost gospodarczy - warunki sukcesu, „Praktyka Polityczna”, nr $1 / 2004$, s. $75-95$.

3) Dane dotyczace współczynników korelacji Pearsona pochodzą z: A. SIWY, A. ADAMCZYK, T. LUBIŃSKA, W. TARCZYŃSKI, Badanie relacji między poziomem fiskalizmu i struktura dochodów podatkowych i parapodatkowych a tempem wzrostu PKB i poziomem bezrobocia $w$ krajach Unii Europejskiej oraz Polsce w okresie 1990-2000, [w:] Polski system podatkowy. Zatożenia a praktyka, pod red. A. POMORSKIEJ, UMCS, Lublin 2004, s. 501-515.

4) Zob szerzej: J. OSTASZEWSKI, Z. FEDOROWICZ, T. KIERCZYŃSKI, Teoretyczne podstawy reformy podatków w Polsce, Difin, Warszawa 2004, s. 100-113.

5) Za: U. MALINOWSKA, Oddziatywanie otoczenia na rozwój przedsiębiorstwa, referat na konferencję naukową Uniwersytetu Łódzkiego w dniach 19-21 maja 2003 r. w Wiśle. 